\title{
LEARNING AND DIGITAL ENVIRONMENT OF DANCE - THE CASE OF GREEK TRADITIONAL DANCE IN YOUTUBE
}

\author{
DimitraGratsiouni [dimitragratsiouni@yahoo.gr],Maria Koutsouba[makouba@phed.uoa.gr],Foteini \\ Venetsanou[fvenetsanou@phed.uoa.gr],VasilikiTyrovola[vtyrovol@phed.uoa.gr],Schoolof Physical \\ Education and Sport Science, National and Kapodistrian University of Athens, Ethnikis Antistasis 41, Dafni, \\ 17237, Greece, [bttp://www.phed.uoa.gr]
}

\begin{abstract}
The incorporation of Information and Communication Technologies (ICT) in education has changed the educational procedures through the creation and use of new teaching and learning environments with the use of computers and network applications that afford new dimensions to distance education. In turn, these emerging and in progress technologies, render new practices in many fields including the field of dance offering a fertile quest to everyone involved in the dance. Yet, a critical evaluation of the content of YouTube dance videos has not been carried out though what is eventually learned through YouTube is a key question. Based on the above, the aim of this study was to critically examine the way YouTube network channel as Computer Based Learning-CBL functions both as a learning tool and as a teaching result concerning the field of dance having as example a Greek traditional dance named Karagouna. YouTube dance videos were gathered through observation, while the dance exemplar used was based on ethnographic research. For the dance recording of the Karagouna performances examined from YouTube, Laban's notation system (Labanotation) was used. For the analysis of the dance performances, the dance structural-morphological and typological method was adopted. Finally, for the comparison of the Karagouna dance performances examined from YouTube with the exemplar of the dancing community, the comparative method was used. It was proved that someone with little or no relation to dance is likely to learn dance with the use of YouTube, yet it is questionable what kind of dance will actually learn since in a number of cases the dance videos do not correspond to the performance of the dancing community. In addition, the outcome is different if someone with prior knowledge on the field of dance (dancer, dance teacher, dance student etc.) uses YouTube as a teaching and learning tool as, in this case, its use is useful and interactive.
\end{abstract}

Key-words: distance learning and teaching, information and communication technologies, YouTube, dance, Greek traditional dance.

\section{Abstract in Greek}

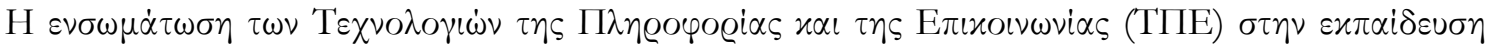

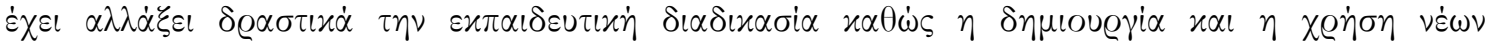

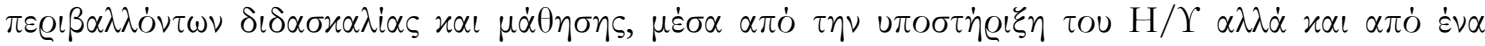

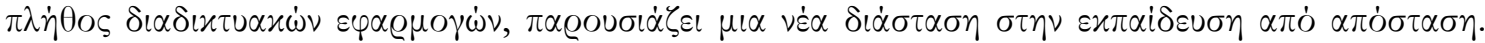

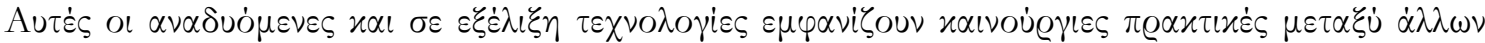

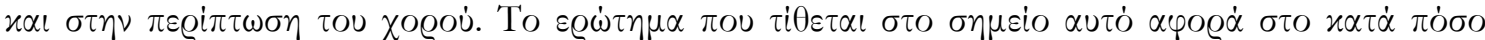

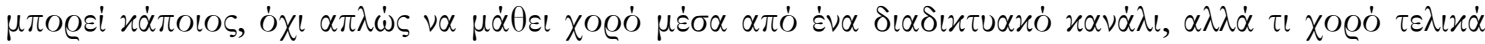

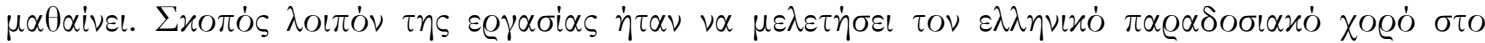

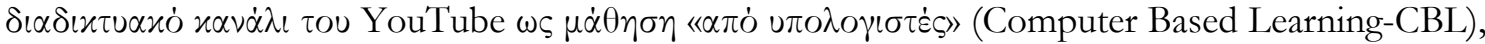

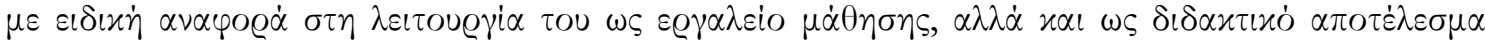




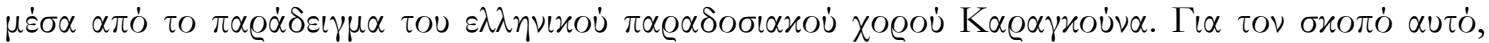

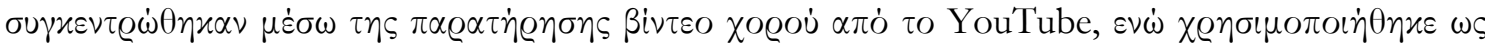

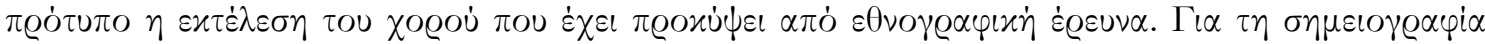

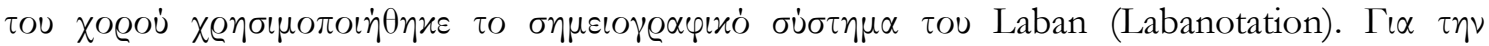

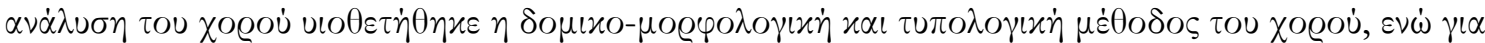

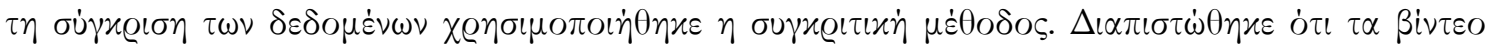

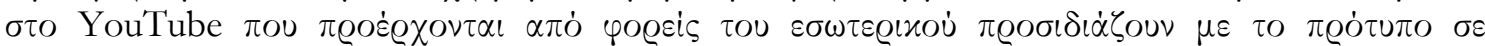

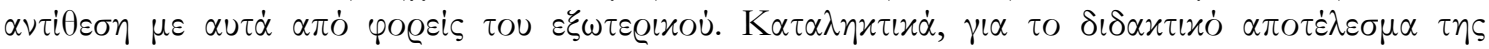

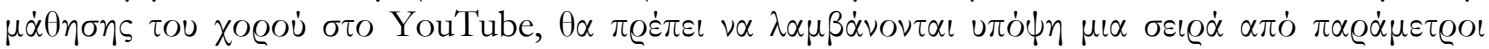

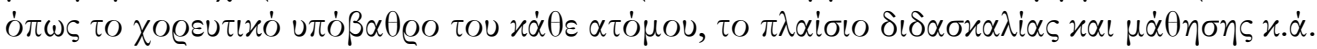

\section{Introduction}

Social networks and social media based on web applications established in ideological and technological findings of the Web 2.0 generation constitute a trademark of today's digital mass culture and grant the production and exchange of content generated by each user (Kaplan \& Heinlein, 2011). Websites like Facebook, Twitter, YouTube etc. predominate internationally for social, educational, entertainment and other purposes, providing the opportunity of (self)exposure and (self)projection to a wide range of audience. A typical example of the existing situation is YouTube (Davidson et al., 2010), the most popular website for video sharing and video common use in the world exceeding one hundred million video uploads per day (Burke \& Snyder, 2008) that establishes a reference point for a participatory culture in the Internet via its spectacular number of video production (Shifman, 2011).

YouTube with its wide popularity offer, inter alia, new opportunities in education (Bonk, 2008) and is used as a learning tool for the classroom and a supplementary component of the overall learning procedure (Karppinen, 2005). Having a strong impact on both the mind and the senses (Berk, 2009), video sharing services inspire students and motivate them to participate in a course supporting their digital learning profile (Burke \& Snyder, 2008). In addition, YouTube constitutes a major educational resource with which students today are fully identified with since the new generation, being so familiar with technology, can be considered as a generation whose computer language might be regarded as their mother tongue (Berk, 2009). In particular, Karppinen (2005, in Snelson, 2008) argued that "online and digital video can be integrated to promote meaningful learning, which was described as being: a) active, b) constructive and individual, c) collaborative and conversational, d) contextual, e) guided, and f) emotionally involving and motivating" (p.216). On these grounds, the extended electronic and virtual reality of the Internet deemed to various interconnection forms of different means and tools, is increasingly affecting teaching and learning processes composing a new quest for education and educational research (Sofos, 2013).

On the other hand, today's demands in education for greater flexibility in space, time and learning pace, have led in the enhancement or even replacement of face-to-face educational processes by distance learning practices (Anastasiades, 2007, 2014; Giossos, Mavroidis, \& Koutsouba, 2008; Lionarakis, 2001, 2006; Red, 2005; Vergidis et al., 1998). The latter have been supported by the use of Information and Communication Technologies (ICT) through the computer networks and especially the Internet (Mouzakis, 2006), either as learning via computers (Computer Based Learning-CBL) or as learning with computers (Computer Assisted LearningCAL) (Thomas Reeves, 1998, in Ringstaff \& Kelley, 2002). From this point of view, the use of YouTube has been studied through various pedagogical theories, while constructivism (Piaget, 1964) seems to be fully applicable since the particular environment of YouTube constitutes a process of information research and discovery emphasizing on both actions and activities of the students themselves despite those among the teaching group (Glasersfeld, 1989; Jonassen, 1999). As Jonassen argued (1999, in Keengwe, Onchwari, \& Wachira, 2008), "technology does not teach 
students; rather, students only learn when they construct knowledge, think and learn through experience" (p.226). Nevertheless, like any other form of educational technology, the teaching value of YouTube largely depends on how it is used.

Among the videos uploaded in YouTube, one encounters the subject of dance as technology is creating a fertile creative background for artists, teachers or researchers focusing on the field (Bailey et al., 2009). However, the way in which art is created, produced, distributed, safeguarded and supported in the market, might take different turns when referring to the transition to a digital society (Poole, 2011). The field of dance could not remain unaffected from this taking into consideration that, throughout dance history, technology has always been a means for its identification, dissemination, storage or display, whether we are referring to written texts or dance recording systems or the use of image or video.

Historically, the use of technology in dance is recorded at the end of the $17^{\text {th }}$ century and the beginning of the $18^{\text {th }}$ in the creations and performances of Loie Fuller (1981's "Serpentine Dance" for instance), an American contemporary dance pioneer (http://en.wikipedia.org/wiki/Loie_Fuller). During the $19^{\text {th }}$ century, dance was incorporated in theatre and cinema, i.e. Hollywood's musicals, Bollywood's movies and Maya Deren, Charles Atlas, David Hinton's etc. dance films (Bench, 2010). In the 1980s, a period with intense research interest for dance teachers, choreographers, researchers and other dance people, particular attention was paid to the use of video as a key means of documentation, analysis and promotion of dance. Moreover, at the same period, researchers or software developers published tools like LabanWriter (https://dance.osu.edu/research/dnb/laban-writer), Dance Forms and LifeForms (http://www.credo-interactive.com), which drew attention to the Laban's dance notation system (Labanotation) and the recording of dance. Processes concerning the rendering technologies with the incorporation of new concepts and the composition through the use of video-projectors, sensors or computer software initiated in the mid-90s (Birringer, 2002). Thereafter, the major storage and transmission of dance until that period took place through films, videos and various TV shows (Bench, 2010).

With the dawn of the $21^{\text {st }}$ century, the capability of editing computer data and the global reach of the Internet led to new thinking and research approaches of dance. The presence of new technologies was radically debated concerning the relationship between body and spatial reality or that between humans and machines. Yet, what needs to be noted is that technology does not solve motion issues attempted through technological means for instance. Rather it is associated with the capacity of exploring interactive environments, virtual spaces and integrated approaches for all those involved with the field of dance (Birringer, 2002). In the past decade, studies have focused on ICT, including YouTube channel, examining the educational potential and needs of distance pedagogical frameworks in general (Leao, 2007; Popat \& Smith-Autard, 2002) and in dance and Greek traditional dance in particular (Antoniou, 2014; Dania, Tyrovola, Koutsouba, \& Hatzacharistos, 2012; Dania, Tyrovola \& Koutsouba, 2013, 2015; Goulimaris, 2015; Goulimaris, Koutsouba, \& Giosos, 2008; Koutsouba \& Giossos, 2006). However, regarding the field of dance in relation to different social networks and social networking websites, the existing studies concern mainly the design and application of programs for online learning (Dimitropoulos, Kitsikidis, \& Grammalidis, 2014; Grammatikopoulou, 2010; Kavakli, Bakoyannis, Damianakis, Loumou, \& Tsatsos, 2004; Leao, 2007; Popat \& Smith-Autard, 2002; Stavridou, 2009). Yet, a critical evaluation of the content of YouTube dance videos has not been carried out though what is eventually learned through YouTube is a key question (Gratsiouni, 2015).

The aim of this study was to critically examine the way YouTube network channel as Computer Based Learning functions both as a learning tool and as a teaching result concerning the field of dance. More specifically, it aimed, through the example of a Greek traditional dance named 
Karagouna, to assess what kind of dance can be learned on YouTube, whether what can be learned is 'correct' in terms of a dance performance that is stood in the dancing society and what are the prerequisites of the dance videos on YouTube in order to do so.

\section{Methodology}

Data collection was twofold. First, the comparator dance exemplar was defined. That was the form of Karagouna dance as this is performed by the local community. Karagouna is a female dance originating from central Greece and specifically from the area of Thessaly. According to Karfis (2014) and Dimopoulos (2011) that have carried out ethnographic research in Thessaly, Karagouna dance has a $4 / 4$ music meter and is performed in open circle that moves predominantly to the right. The dance has six different ways in which it can be performed by the dancing community, i.e. community of Thessaly (Appendix 1). These six forms constituted the comparator dance exemplar of this study. In order to clarify and enhance the already existing ethnographic data, interviews with the two aforementioned researchers were carried out (Dimopoulos, 2014; Karfis, 2014).

Regarding the YouTube videos of the Greek traditional dance Karagouna, data were gathered through observation. In particular, the research process on YouTube followed six stages:

- In the first stage, all potential tags regarding the specific dance were searched in accordance to the options available on the website. If, for example, in the searching tool of the website the word Karagouna is typed, many more options related to the initial search are automatically loaded. Hence, in this process, 15 related to the term tags in total have

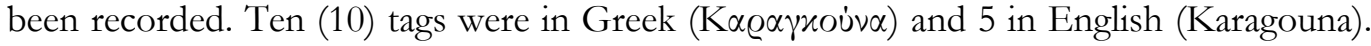
The search was carried out from the $21^{\text {st }}$ of November until the $27^{\text {th }}$ of December 2013.

- At the second stage, as thousands of videos were found under these tags, a selection took place based on the following criteria related to dance itself: (a) the title of the video should include the term Karagouna in any version, (b) the video should exclusively present the dance Karagouna itself and not relate to any kind of event in general e.g. a festival, (c) the video should show the movement of the whole body and not its parts separately (legs, upper body etc.) and (d) video sound and image should be distinct. 772 videos on YouTube of the Karagouna dance were thus revealed.

- At a third stage, the 772 videos were classified with all the necessary information related to them: (a) the title of the video, (b) the Uniform Resource Locator (URL), (c) respective institution (if any) (d) the uploader (the user which uploads the video), (e) information provided concerning the origin of the video, ( $\mathrm{f}$ ) views in total (how many people have seen each video), (g) date of posting (when it has been uploaded), (h) register date (when the researcher listed the video), (i) the video in mp4 format with audio and image and (j) the application of like/dislike (registered users vote for or against the video).

- In the fourth stage, these 772 videos have been sorted out. It was found that the total of 772 videos was in fact 190 different videos which through various combinations were shown in the diverse tags, i.e. there were same videos uploaded by different users in different tags.

- In the fifth stage, the 190 videos were additionally classified based on the following two criteria: (a) videos most viewed on YouTube and (b) videos found in almost all 15 searches-tags of the dance on YouTube. These two criteria related to the use of YouTube since both the number of views and the frequent occurrence in searches-tags refers to the user's accessibility to them, a fact with great importance for the examined issue. In this 
stage it was revealed that 7 videos were the most viewed (above 50,000) (criterion a), while 20 videos found in almost all tags (criterion b).

- In the sixth stage, 19 videos of Karagouna dance on YouTube that met both the criterion of mostly viewed on YouTube along with the criterion of frequent search occurrence in all 15 searches-tags of the dance on YouTube were chosen for further analysis and study (see Appendix 2). Among these videos, twelve (12) were from Greek institutions and seven (7) from institutions abroad.

The Karagouna dance of these 19 YouTube videos was then recorded, analyzed and compared with the exemplar. For the recording, Laban's notation system called Labanotation was used. Labanotation is an internationally recognized system for recording movement and dance on paper (Hutchinson, 1977; Hutchinson-Guest, 1984; Koutsouba, 2005) which, through the use of abstract symbols, captures and represents the movements of all parts of the body in space and time. In that way, Labanotation captures the structure and thus the construction of the dance in relation to its musical accompaniment (Koutsouba, 2003, 2005; Tyrovola \& Koutsouba 2007). Below is an example of the recording of one of the 19 YouTube videos of Karagouna dance with Labanotation (see Figure 1).

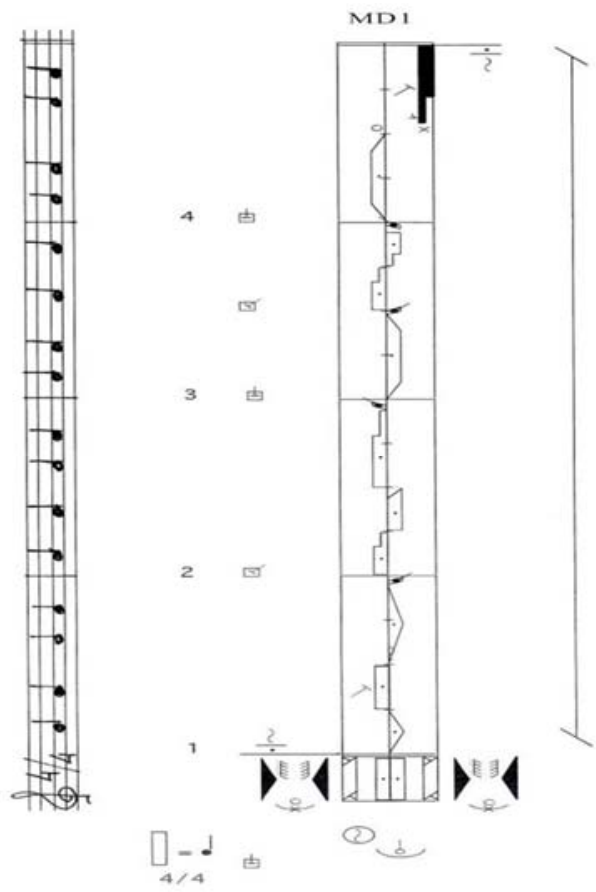

Figure 1. Labanotation of dance "MD1 - Dimotika Thessalias, 02, 'Karagkouna'”

After their recording with Labanotation, the dance performances of all the 19 videos were analysed by using the structural-morphological and typological method (Tyrovola, 1994, 2001; Koutsouba, 1997, 2007). Structural-morphological and typological method concerns the structure and form of the dance. It constitutes a synthesis of previous methods, i.e. the one introduced by the IFMC Study Group for Folk Dance Terminology (1974) concerning the relationship between dance and music and three presented by Giurchescu (1986), Sanchez-Colberg (1992) and Adshead et al. (1988) regarding the classification of the dance components. Below is an example of the analysis of one of the 19 YouTube videos of Karagouna dance based on the structuralmorphological and typological method (see Table $1 \& 2$ ). 
Table 1: Codification and typology of dance "MD1 - Dimotika Thessalias, 02, 'Karagkouna”"

\begin{tabular}{|c|}
\hline M1 - Dimotika Thessalias, 02, "Karagkouna" \\
\hline $\mathrm{F}=\stackrel{\mathrm{M}}{\rightarrow}\left[\left(\delta^{1 / 4}-\alpha>\delta^{1 / 4}\right)+\delta^{2 / 4}\right]+\underset{\rightarrow}{\operatorname{M}}\left[\left(\alpha^{1 / 4}-\delta>\alpha^{1 / 4}\right)+\alpha^{2 / 4}\right]+$ \\
\hline $\mathrm{M} 3\left[\delta^{2 / 4}+\left\{\alpha(\delta)^{x / 4}-\delta^{1 / 4}\right\}\right]+\mathrm{M} \underset{\leftarrow}{L}\left[\alpha_{0}^{2 / 4}+\left(\alpha_{0}\right) \delta_{4}{ }^{2 / 4}\right]$ \\
\hline
\end{tabular}

Table 2: Components of dance "MD1 - Dimotika Thessalias, 02, 'Karagkouna'”

\begin{tabular}{|c|c|}
\hline Components of & Dance MD1 - Dimotika Thessalias, 02, "Karagkouna” \\
\hline Movement & $\begin{array}{l}\text { Movements: Moderate, slow leg movements with simple movements in space, } \\
\text { postures and low deadlifts. The body is in upright position } \\
\text { Space: Circular shape, open circle directed towards the right. Group dance that } \\
\text { characterized by the participation of many people. } \\
\text { Time: Meter of the dance music: } 4 / 4 \\
\text { Music tempo: Slow and steady intensity }\end{array}$ \\
\hline Dancers & $\begin{array}{l}\text { Gender: women only } \\
\text { Handhold: From the palms with stretched elbows (handhold M). From the palms } \\
\text { with elbows bent between first and second dancer (handhold W) }\end{array}$ \\
\hline $\begin{array}{l}\text { Visual } \\
\text { environment }\end{array}$ & $\begin{array}{l}\text { Performance area: Studio-Television show } \\
\text { Costumes: Traditional costume for Karagouna women }\end{array}$ \\
\hline Audio elements & Music accompaniment: Accompanied by live traditional music with song \\
\hline Complex & $\begin{array}{l}\text { Model of dance form: homogenous chain dance form, i.e. one dance phrase that } \\
\text { is repeated } \\
\text { Choreography: Continuous repetition of the dance phrase throughout the dance } \\
\text { performance }\end{array}$ \\
\hline
\end{tabular}

Finally, for the comparison of the Karagouna dance performances examined from YouTube with the exemplar of the dancing community, the comparative method was used (Collier, 1993; Thomas \& Nelson, 2003). In particular, the recordings with Labanotation, the structuralmorphological and typological analysis and the dance components of each one of the 19 YouTube videos of Karagouna dance was compared with the six forms constituted the comparator dance exemplar of the present study.

\section{Results}

The YouTube search of one Greek traditional dance, Karagouna, revealed a large number of videos, a finding showing the active presence of dance in general and of Greek traditional dance in particular on YouTube.

However, the comparison of the recordings with Labanotation, the structural-morphological and typological analysis and the dance components of each one of the 19 YouTube videos of Karagouna dance with the six forms that constituted the comparator dance exemplar of the present study, i.e. the dance as it is performed by the local community, showed that twelve (12) matched to one of the six forms of the exemplar. These videos presented the same characteristics in terms of the performance as well as in terms of the construction of the dance, i.e. performed by women, danced with the use of similar movements etc. For instance, the performance of Karagouna dance in no1 YouTube video, i.e. "MD1-Dimotika Thessalias, 02, 'Karagkouna"' (see 
Figure 1 and Tables 1 \& 2) corresponds to the exemplar 5 (see Appendix 1) since both present the same characteristics: a dance phrase performed by women that have 11 movements organized in two groups (kinetic motifs) that are completed in 4 musical meters.

On the other hand, seven (7) YouTube videos of Karagouna dance did not match to any of the six forms of the exemplar, presenting different characteristics in their performance and/or their construction, i.e. performed by men and women, danced with the use of different movements etc. For instance, in the YouTube video no 10 (see Figure 2 and Tables 3 \& 4), the dance form of Karagouna dance consists of three parts, while all the six forms of the exemplar have one part. Moreover, the comparison showed that there was only one similarity with the exemplar, that was Part A corresponding to the exemplar 2 as both presented similar characteristics (a dance phrase that has 8 movements organized in four groups, i.e. kinetic motifs, that are completed in 4 musical meters), while Part B and C did not match to any form of the exemplar. Furthermore, both Dimopoulos (2014) and Karfis (2014) argued that this video dance form "constitutes a choreographic devise that is usually called the 'Karagouna dance of the school'. This choreography has been adopted mainly for school events so as to be more impressive".

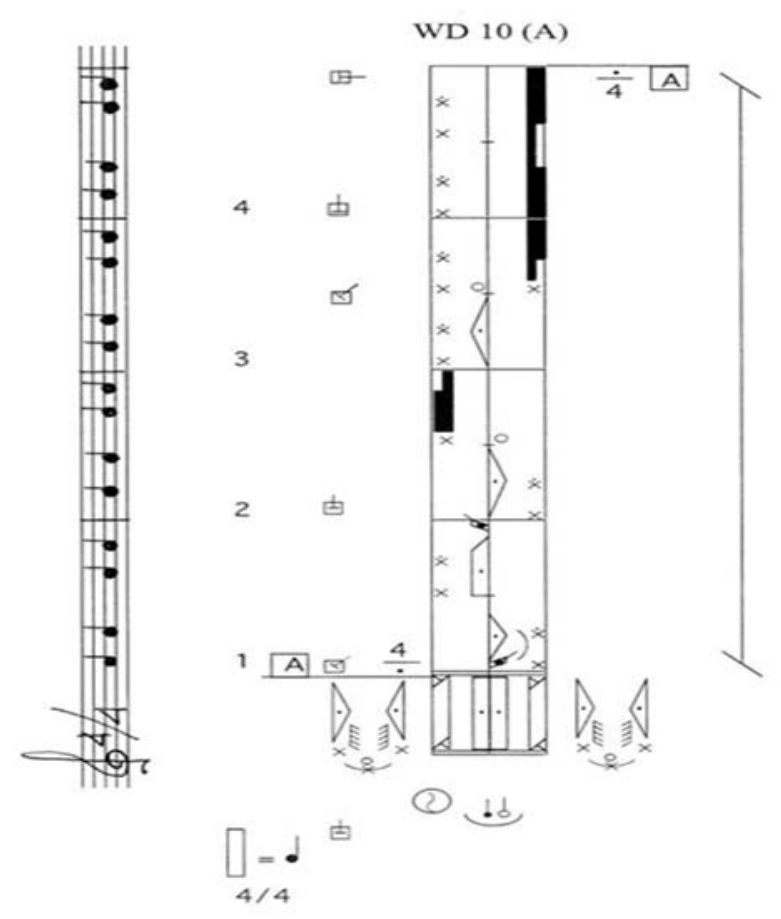


Learning and Digital Environment of Dance - The Case of Greek Traditional Dance in YouTube Dimitra Gratsiouni et al.

WD10 (B)
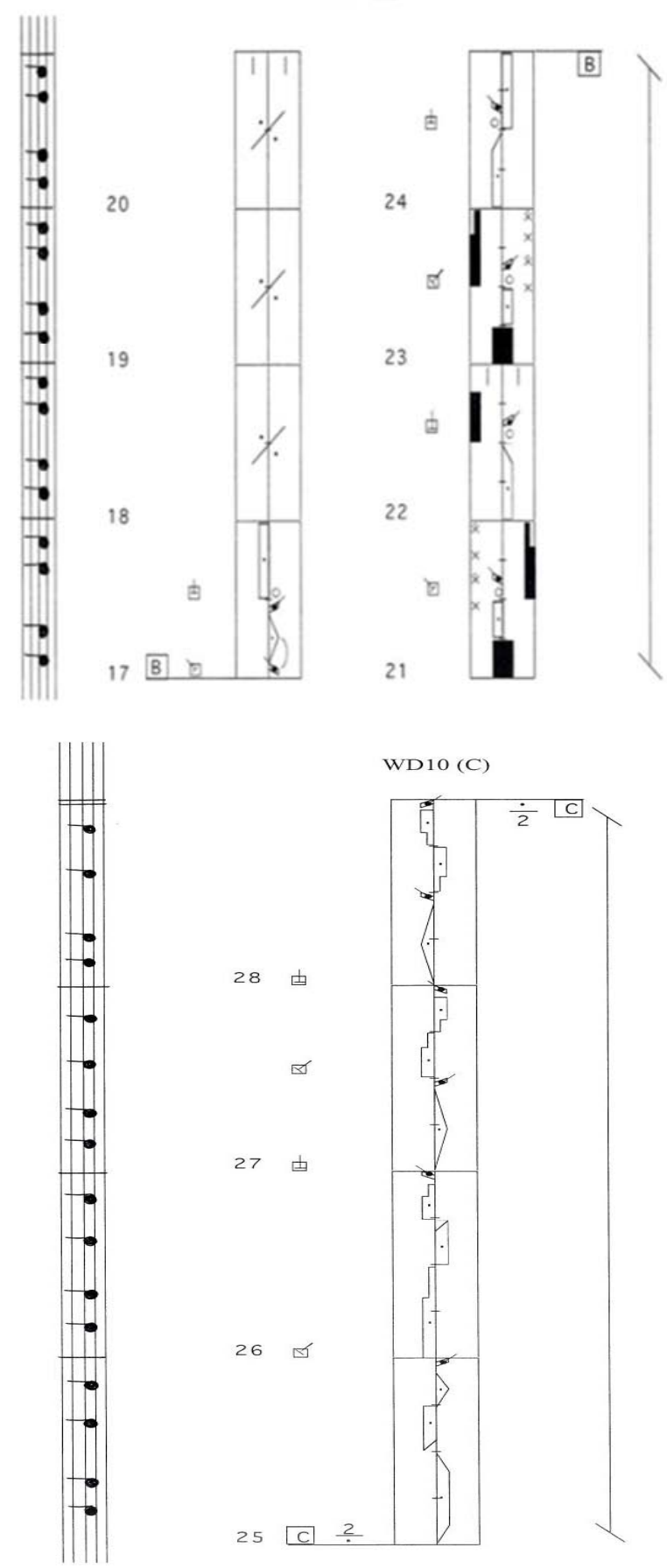

Figure 2. Labanotation of dance "WD10 - Karagouna" 
Table 3: Codification and typology of dance "WD10 - Karagouna"

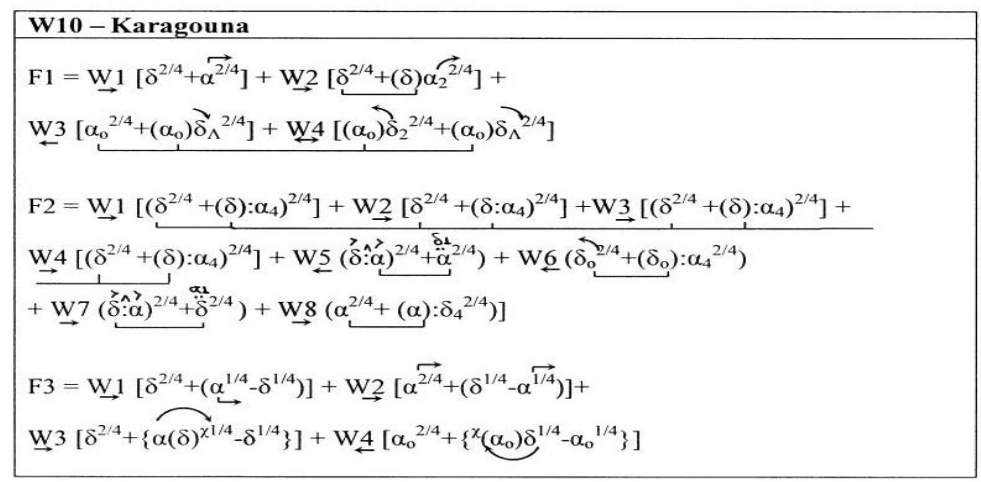

Table 4: Components of dance "WD10 - Karagouna"

\begin{tabular}{|c|c|}
\hline $\begin{array}{l}\text { Components of } \\
\text { dance }\end{array}$ & Dance WD10 - Karagouna \\
\hline Movement & $\begin{array}{l}\text { Movements: The dance consists of three parts. Part A has steps, pauses and lifts } \\
\text { of the feet. Part B has steps, pauses, lifts of the feet in low level and jumps, while } \\
\text { there is change in directions. Part C has quick steps } \\
\text { Space: Open circle that moves towards the right. Group dance that characterized } \\
\text { by the participation of many people. } \\
\text { Time: Music meter in } 4 / 4 \text { with slow tempo and steady intensity in Part A and B } \\
\text { and quick in Part C }\end{array}$ \\
\hline Dancers & $\begin{array}{l}\text { Gender: Men and women mixed up. } \\
\text { Handhold: From the palms with elbows bent (handhold W) }\end{array}$ \\
\hline $\begin{array}{c}\text { Visual } \\
\text { environment }\end{array}$ & $\begin{array}{l}\text { Performance area: Classroom } \\
\text { Costumes: Daily uniform }\end{array}$ \\
\hline Audio elements & $\begin{array}{l}\text { Music accompaniment: Accompanied by organic traditional music with song and } \\
\text { sound system }\end{array}$ \\
\hline Complex & $\begin{array}{l}\text { Model of dance form: A three part, alternating dance form with the parts being } \\
\text { heterogeneous } \\
\text { Choreography: Three parts, each one constituting one dance phrase this is } \\
\text { repeated } 4 \text { times in Part A, } 2 \text { in Part B and Part C, while altogether is repeated for } \\
\text { three times }\end{array}$ \\
\hline
\end{tabular}

It should be also noted that the twelve (12) that match to the exemplar were from Greek institutions, while the seven (7) from institutions abroad did not.

\section{Discussion-Conclusion}

Distance learning through the support of technological media can be used either supplementary or exclusively in all stages and forms of education as well as an independent process through which each user-learner opts for the means of learning by the use of computers and the Internet. The latter procedure is directly connected to the aim of this study since one can learn dance via YouTube videos. The question though was what kind of dance one learns (Gratsiouni, 2015). The aim of this study was to critically investigate the way YouTube network channel as Computer Based Learning functions both as a learning tool and as a teaching result concerning the field of dance. For that purpose, through the example of a Greek traditional dance named Karagouna, it was assessed what kind of dance can be learned on YouTube, whether what can be learned is correct in terms of a dance performance that is stood in the dancing society and what are the prerequisites of the dance videos on YouTube in order to do so. The results showed that there is a high degree of user's accessibility to YouTube videos of Karagouna dance, thus these videos can be used for learning reasons. Yet the learning outcome differs. The comparison between the Karagouna dance in YouTube videos and as it is performed by the local community 
showed that not all dance forms being uploaded on the channel matched to those being adopted by the dance community. This finding points out that though someone with little or no relation to dance is likely to learn dance with the use of YouTube, it is questionable what kind of dance will actually learn since, in many cases, the dance videos do not correspond to the performance of the dancing community. On the other hand, the outcome is different if someone with prior knowledge on the dance field (dancer, dance teacher, dance student etc.) uses YouTube as a teaching and learning tool as, in this case, its use is useful and interactive.

Based on the above, it is proved that the study of Greek traditional dance as learning from computers fully responds to the framework determined by the YouTube network. This independent learning process that defines students as teachers and serves to increase the basic skills and knowledge of learners, functions positively on the subject of Greek traditional dance in general since YouTube, as a learning tool but also as a projection tool, creates new learning practices of Greek traditional dance. Without any doubt, this multilevel and multifocal YouTube procedure in the light of aestheticization, disclosure, reproduction and communication, composes a form of creativity and discovery of new practices for dance (Papakostas, 2012) and dance distance education that were confirmed through the study of the dance Karagouna.

However, the answer to the question whether or not a network user and specifically YouTube user may identify the correct dance form in order to learn dancing depends on the presence or absence of a dancing background of the user. It is proved that certain prerequisites such as the cultural background and the dance knowledge of the people, the teaching-learning context in which the videos are used etc., should be met so as to give credentials to this kind of learning, at least in the case of the subject matter of dance.

In conclusion, the rapid and increasing use of technology and the Internet from people of all ages imposes the adjustment, adoption and incorporation of new data in learning practices. Although some may stand critical towards the new achievements as learning tools, research demonstrates the contrary by illustrating through the means of distance learning and the use of ICT new, attractive and creative methods of learning. Based on the demands of an ever changing society through the rapid spread of the Internet, the necessity of the incorporation of dance becomes explicit along with the Greek traditional dance in the contemporary situation under certain conditions though. In any case, the study of dance in general and of Greek traditional dance in particular, constitutes an unprecedented and growing field of research that opens new perspectives in the study and research forming a new framework of the presence of dance, that of the Internet.

\section{References}

1. Adshead, J., Briginshaw, V., Hodgens, P., Huxley, M., et al. (1988). Dance analysis: theory and practice. London: Dance Books.

2. Anastasiades, P. (2014). Research on DL with the use of ICT (e-learning) in the Greek typical educational system. Review and prospects for primary, secondary and higher education. Open Education-The Journal for Open and Distance Education and Educational Technology, 10(1), 5-32.

3. Antoniou, P. (2014). The Video in Teaching Dance. The Approach of YouTube. Science of Dance, 7, 11-46. Retrieved from http://elepex.gr/images/stories/evdomostomos/antoniou_full_paper_1_gr.pdf

4. Bailey, H., Bachler, M., Buckingham Shum, S., Le Blanc, A., Popat, S., Rowley, A., \& Turner, M. (2009). Dancing on the grid: using e-science tools to extend choreographic research. Philosophical Transactions: Mathematical, Physical and Engineering Sciences, 367(1898), 2793-2806. 
5. Bench, H. (2010). Screendance 2.0: Social dance-media. Journal of Audience \& Reception Studies, 7(2), 183-214.

6. Berk, R. A. (2009). Multimedia teaching with video clips: TV, movies, YouTube, and mtvU in the college classroom. International Journal of Technology in Teaching and Learning, 5(1), 1-21.

7. Birringer, H. (2002). Dance and media technologies. Journal of Performance and Art, 24(1), 8493.

8. Bonk, C. J. (2008). YouTube anchors and enders: The use of shared online video content as a macrocontext for learning. New York: American Educational Research Association (AERA).

9. Burke, S. C., \& Snyder, S. L. (2008). YouTube: An innovative learning resource for college health education courses. International Electronic Journal of Health Education, 11, 39-46.

10. Collier, D. (1993). The Comparative Method. In A. W. Finifter (Ed.), Political Science: The State of the Discipline II. Washington D.C.: American Political Science Association.

11. Credo-interactive.com (2016). Dance Forms 2 - Life Forms 5. Retrieved from http://www.credo-interactive.com

12. Dania, A., Hatziharistos, D., Koutsouba, M., \& Tyrovola, V. (2011). The use of technology in movement and dance education: recent practices and future perspectives. Procedia, Social \& Behavioral Sciences, 15, 3355-3361. Retrieved from http://www.sciencedirect.com/science/article/pii/S1877042811008457

13. Dania, A., Tyrovola, V., Koutsouba, M., \& Hatziharistos, D. (2012). Labankido@: The evaluation of a multimedia tool designed for the teaching of basic skills and concepts in dance education. The International Journal of Sport and Society, 3(3), 137-148. Retrieved from http://ijr.cgpublisher.com/product/pub.191/prod.156

14. Dania, A., Koutsouba, M., \& Tyrovola, V. (2013). Labankido(C: a technological application for the distance learning of Greek traditional dance. In A. Lionarakis (Ed.), Learning Methodologies, Proceedings of the $7^{\text {th }}$ International Conference on Open and Distance Learning (vol. 3, pp. 144-157). Athens: Hellenic Network for Oren and Distance Education. Retrieved from http://icodl.openet.gr/index.php/icodl/2013/schedConf/presentations

15. Dania, A., Koutsouba, M., \& Tyrovola, V. (2015). The ability of using symbols and its contribution to dance learning: The Laban notation system. Choros International Dance Journal, 4, 37-49. Retrieved from https://app.box.com/s/dcfnfsx5z4hoipdvhvgg4ji176bfup5n

16. Davidson, J., Liebald, B., Liu, J., Nandy, P., \& Van Vleet, T. (2010). The YouTube video recommendation system. Proceedings of the $10^{\text {th }}$ ACM Conference on Computer Supported Cooperative Work, 293-296. US: Association for Computing Machinery (ACM) Digital Library.

17. Dimitropoulos, K., Kitsikidis, A., \& Grammalidis, N. (2014). Information Technologies in Traditional Dance Analysis. Science of Dance, 7, 1-10. Retrieved from http://elepex.gr/images/stories/evdomostomos/dimitropoulos_full_text_gr.pdf

18. Dimopoulos, K. (2011). The components of space and gender dance perspectives. Lowland and mountainside communities of Karditsa Thessaly during the period 1920-1980. Unpublished Master Dissertation. Athens: School of Physical Education and Sport Science, National and Kapodistrian University of Athens.

19. Dimopoulos, K. (2014). Personal Interview. Athens. 
20. Giosos, I., Mavroides, I., \& Koutsouba, M (2008). Research on distance learning: Review and

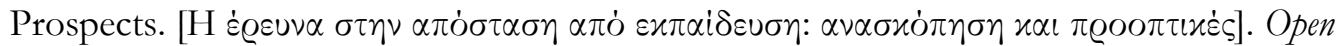
Education-The Journal for Open and Distance Education and Educational Technology, 4(1), 49-60.

21. Giurchescu, A. (1986). Power and Charm. Interaction of Adolescent Men and Women in Traditional Settings of Transylvania. Yearbook for Traditional Music, 18, 37-46. Retrieved from http://www.jstor.org/stable/768518?seq=1\#page_scan_tab_contents

22. Glasersfeld, E. (1989). Constructivism in education. In T. Husen \& T. N. Postlethwaite (Eds.), The International Encyclopedia of Education, Supplement (vol. 1, pp. 162-163). Oxford and New York: Pergamon Press.

23. Goulimaris, D. (2015). The relation between distance education students' motivation and satisfaction. Turkish Online Journal of Distance Education, 16(2), 13-27. Retrieved from http://tojde.anadolu.edu.tr/upload/files/tojde_16_2_2015.pdf

24. Goulimaris, D., Koutsouba, M., \& Giosos, Y. (2008). The organization of a distance postgraduate dance program and the participation of students specializing in dance. Turkish Online Journal of Distance Education, 9(3), 59-73. Retrieved from http://tojde.anadolu.edu.tr/yonetim/icerik/makaleler/424-published.pdf

25. Grammatikopoulou, A. (2010). Application of virtual reality in distance learning: Distance teaching of Greek folklore dance support. Unpublished undergraduate thesis. Thessaloniki: School of Physical Education and Sport Science, Aristotle University of Thessaloniki.

26. Gratsiouni, D. (2015). Learning and digital environment. The case of Greek folk dance in the networking channel YouTube. Unpublished master dissertation. Athens: School of Physical Education and Sport Science, National and Kapodistrian University of Athens.

27. Hutchinson, A. (1977). Labanotation: The System for Analyzing and Recording Movement on Paper (3 ed.). London: Dance Books.

28. Hutchinson Guest, A. (1984). Dance Notation: The Process of Recording Movement on Paper. London: Dance Books.

29. IFMC Study Group for Folk Dance Terminology (1974). Foundations for the analysis of the structure and form of folk dance: a syllabus. Yearbook for Folk Music, 6, 115-135.

30. Jonassen, H. D. (1999). Designing constructivist learning environments. In C.M. Reigeluth (Ed.), Instructional design theories and models: A new paradigm of instructional theory (volume II, pp. 215-239). New York and London: Routledge.

31. Kaplan, A., \& Haenlein, M. (2011). Two hearts in three-quarter time: How to waltz the social media/viral marketing dance. Business Horizons, 54, 253-263.

32. Karfis, V. (2014). Personal Interview. Athens.

33. Karpinnen, P. (2005). Meaningful learning with digital and online videos: Theoretical Perspectives. Association for the Advancement of Computing in Education Journal, 13(3), 233-250.

34. Kavakli, E., Bakoyanni, S., Damianakis, A., Loumou, M., \& Tsatsos, D. (2004). Traditional dance and e-learning: The Webdance learning environment. Proceedings of the International Conference on Theory and Applications of Mathematics and Informatics. Thessaloniki, Greece.

35. Keengwe, J., Onchwari, G., \& Wachira, P. (2008). The use of computer tools to support meaningful learning. AACE Journal, 16(1), 77-92. 
36. Koutsouba, M. (1997). Plurality in Motion: Dance and Cultural Identity on the Greek Ionian Island of Lefkada. Ph.D. thesis. London: Music Department, Goldsmiths College, University of London, UK.

37. Koutsouba, M. (2003). Melody, speech and movement through distance polymorphic learning: a first approach. In K. Panopoulou (Ed.), Melody, Speech, Movement, Proceedings of $2^{\text {nd }}$ Pan-Hellenic Conference of Popular Culture for Melody, Speech and Movement (pp. 195-204). Serres: Municipality of Serres.

38. Koutsouba, I. M. (2005). Notation of the Dancing Movement. The passage from the prehistory to the

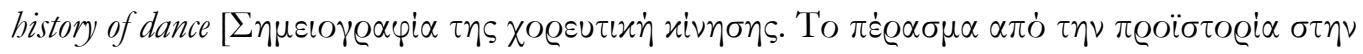

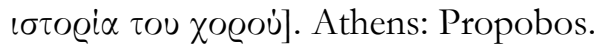

39. Koutsouba, M. (2007). Structural analysis for Greek folk dance. A methodology. In A. L. Kaeppler \& E. I. Dunin (Eds.), Dance Structures: Perspectives on the Analysis of Human Movement (pp. 253-276). Budapest: European Folklore Institute.

40. Koutsouba, M., \& Giossos, Y. (2006). A model for motor learning in distance polymorphic education: the case of performance arts and dance. Open Education-The Journal for Open and Distance Education and Educational Technology, 4, 33-44. Retrieved from http://journal.openet.gr/index.php/openjournal/article/viewArticle/47

41. Lionarakis, A. (2001). Open and distance polymorphic education. Considerations for a

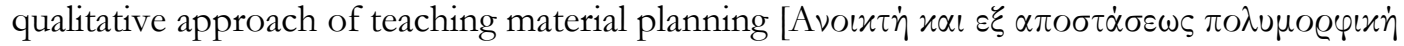

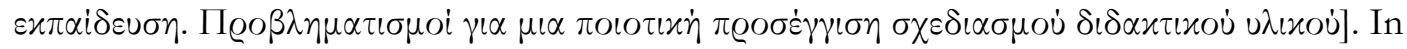
A. Lionarakis (ed.), Thoughts and Considerations for Open and Distance Education (pp. 33-52). Athens: Propobos.

42. Lionarakis, A. (2006). The theory of distance education and the complexity of its

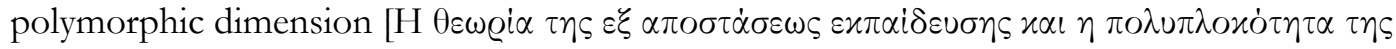

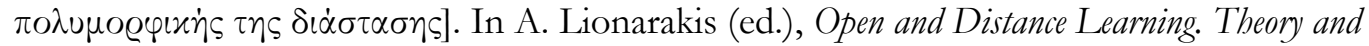
Practice (pp. 33-52). Athens: Propobos.

43. Leao, L. (2007). Corposcopio: an interactive installation performance in the intersection of ritual, dance and new technologies. Technoetic Arts: A Journal of Speculative Research, 5(2), 113117.

44. Mouzakis, X. (2006). Teaching Adults-8. Distance learning in adult education-Examples and application cases. Athens: Ministry of Education.

45. Ohio State University, Dance Department (2016). Labanwriter. Retrieved from https://dance.osu.edu/research/dnb/laban-writer

46. Papakostas, Ch. (2012). "A La Turka”. Musical representations of the ethnic and the national. About a Folkore on YouTube. In E. Avdikos (Ed.), The Folklore Studies in Greece and Turkey (pp. 245-286). Athens: Pedio.

47. Piaget, J. (1964). Cognitive development in children: Piaget development and learning. Journal of Research in Science Teaching, 2, 176-186.

48. Poole, D. (2011). Digital transitions and the impact of new technology on the arts. Canadian Public Arts Funders Network, 2-64.

49. Popat, S., \& Smith-Autard, J. (2002). Dance-making on the internet: Can on-line choreographic projects foster creativity in the user-participant? Leonardo, 35(1), 31-36. 
50. Ringstaff, C., \& Kelley, L. (2002). The Learning Return on our Educational Technology Investment. A Review of Findings from Research. San Francisco, West Ed RTEC.

51. Sanchez-Colberg, A. (1992). German Tan₹theater: Traditions and Contradictions a Choreological Documentation of Tanztheater from its Roots in Ausdrucktanz to the Present. Ph. D thesis. Retrieved from https://www.researchgate.net/publication/293440297_The_original_version_of_the_PhD_ dissertation_written_in_1992_A_first_and_seminal_analysis_in_English_of_the_work_of_Pi na_Bausch_and_the_Wuppertal_Tanztheater_It_critically_examines_the_term_\%27tanzthea $\mathrm{t}$

52. Shifman, L. (2011). An anatomy of a YouTube meme. New Media \& Society, 14(2), 187-203.

53. Snelson, C. (2008). Web-Based video in education: Possibilities and pitfalls. Proceedings of the Technology, Colleges \& Community Worldwide Online Conference, 214-221. Hawaii: University of Hawaii.

54. Sofos, A. (2013). Situational environments for modern learning. In Open Education-The Journal for Open and Distance Education and Educational Technology, 9(1), 62-74.

55. Stavridou, E. (2009). Applications of multimedia technologies and Internet educational environments to support distance learning Greek traditional dances. Unpublished undergraduate thesis. Thessaloniki: School of Physical Education and Sport Science, Aristotle University of Thessaloniki.

56. Thomas, J. R., \& Nelson, J. K. (2003). Research Methods in Physical Activity. (Ed. by K. Karteliotis). Athens: Pashalides.

57. Tyrovola, V. (1994). The dance 'sta tria' in Greece. Structural-morphological and typological approach of the form of 'sta tria' dance. Ph.D. Thesis. Athens: Department of Music, National and Kapodistrian University of Athens.

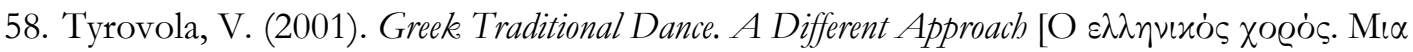

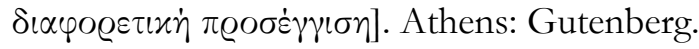

59. Tyrovola, V., \& Koutsouba, M. (2007). Choreology and dance: From the act of dance to the scientific theory. Critical observations. Buletin Stiintific, Seria: Educatie Fizica si Sport, Editura Universitatii din Pitesti, Romania, II(1), 27-33.

60. Vergidis, D., Lionarakis, A., Lykourgiotis, A., Makrakis, B., \& Matralis, Ch. (1998). Open and distance learning, vol. 1. Patra: Institution and Operation, Hellenic Open University. (in Greek; title of book translated by paper authors). 


\section{Appendix 1. Exemplar of Karagouna dance with six different ways}
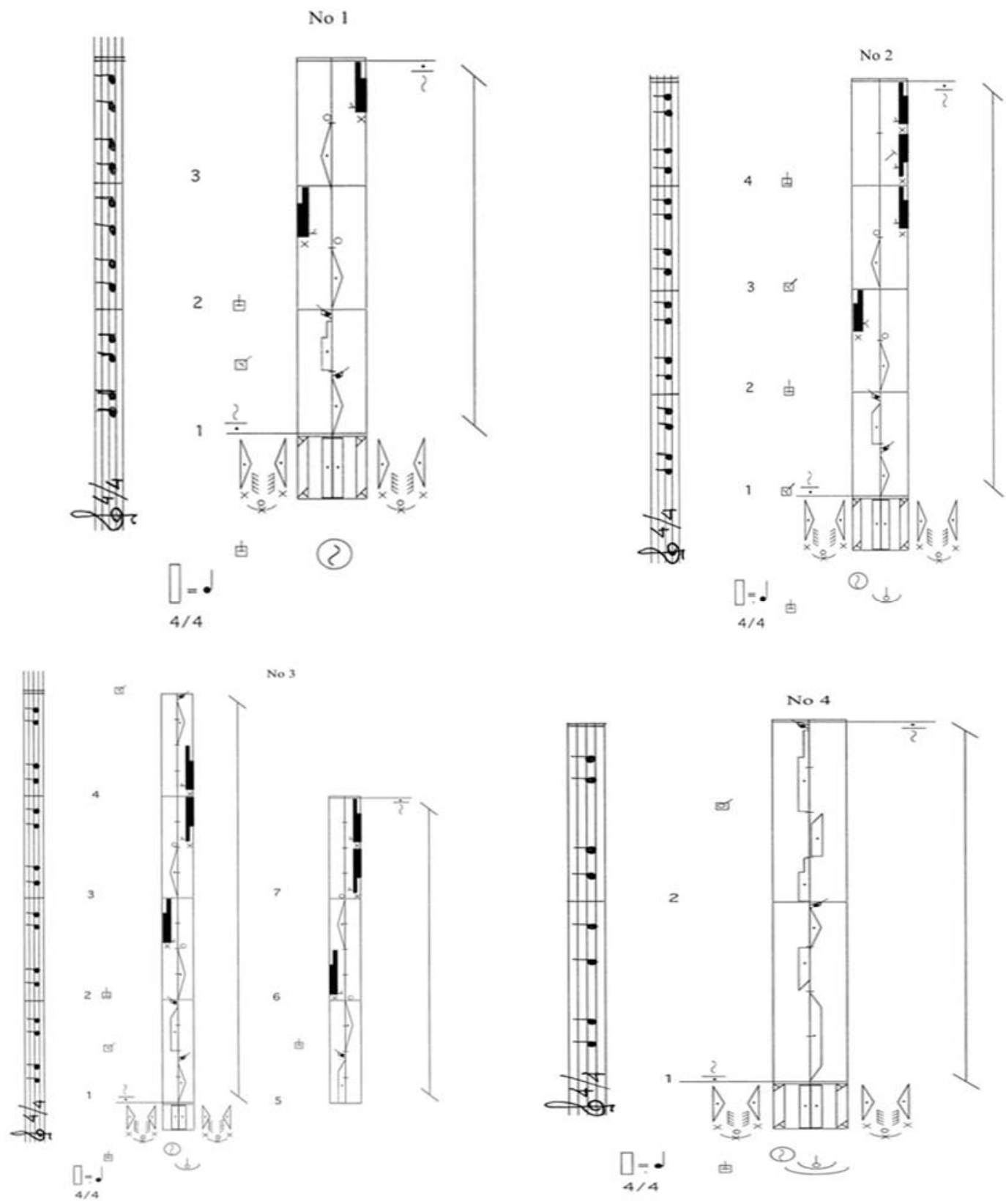

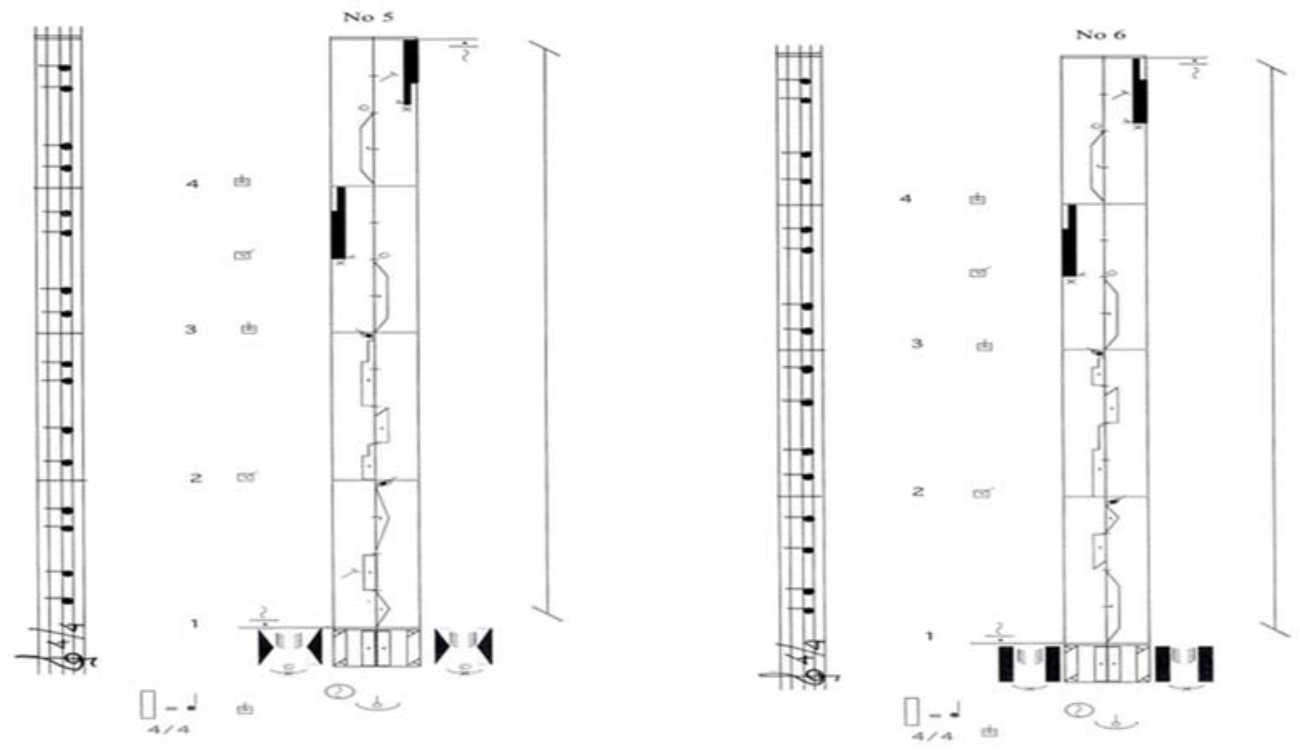

\section{Appendix 2. Under study Karagouna dance videos from YouTube}

\begin{tabular}{|c|c|c|c|c|c|c|}
\hline no & Title & Link (URL) & Institutions & Views & Date posted & Date recovery \\
\hline 1. & $\begin{array}{l}\text { DimotikaThessalias, 02, } \\
\text { "Karagkouna" }\end{array}$ & www.youtube.com/watch?v=IHIz_1ds7v0 & In Greece & 154.597 & 9.6 .2009 & 21.11 .2013 \\
\hline 2. & 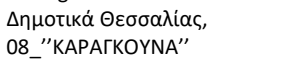 & www.youtube.com/watch?v=sy7fcF7CLOM & In Greece & 58.464 & 20.3.2011 & 21.11.2013 \\
\hline 3. & Karagouna & www.youtube.com/watch?v=oQzc4TzOA_Q & Outside Greece & 78.880 & 31.8 .2007 & 28.11.2013 \\
\hline 4. & $\begin{array}{l}\text { Greek Folk Dance- } \\
\text { Karagouna }\end{array}$ & www.youtube.com/watch?v=7odP0F16igw & Outside Greece & 109.022 & 21.9.2007 & 28.11 .2013 \\
\hline 5. & 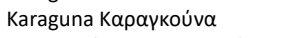 & www.youtube.com/watch?v=O9DBLOnCoOw & In Greece & 79.446 & 17.12 .2008 & 21.11.2013 \\
\hline 6. & 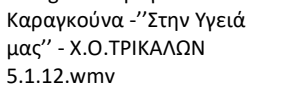 & www.youtube.com/watch?v=OhRj_Spl-AQ & In Greece & 7.021 & 7.1.2012 & 21.11 .2013 \\
\hline 7. & 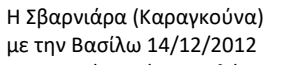 & www.youtube.com/watch?v=vVGhcnmGy3w & In Greece & 3.940 & 14.12.2012 & 21.11.2013 \\
\hline 8. & 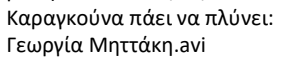 & www.youtube.com/watch?v=Wt1cMHfBYEg & In Greece & 6.582 & 26.1.2012 & 21.11.2013 \\
\hline 9. & 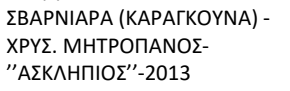 & www.youtube.com/watch?v=sYA2OVeFvqw & In Greece & 1.580 & 24.5.2013 & 21.11.2013 \\
\hline 10. & Karagouna & www.youtube.com/watch?v=H7JUeWPMIfc & Outside Greece & 16.274 & 12.11 .2008 & 28.11.2013 \\
\hline 11. & 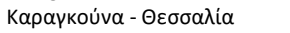 & www.youtube.com/watch?v=ODXyoy3kPEo & In Greece & 31.312 & 4.5.2012 & 21.11.2013 \\
\hline 12. & 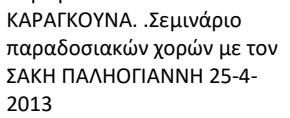 & www.youtube.com/watch?v=1177UnrmcT0 & In Greece & 327 & 27.4 .2013 & 21.11 .2013 \\
\hline 13. & $\begin{array}{l}\text { 13. Karagouna (by Meltemia } \\
\text { dancers and Souvlaki } \\
\text { Orchestra) }\end{array}$ & www.youtube.com/watch?v=2hW8-grX6q8 & Outside Greece & 901 & 25.5.2012 & 28.11.2013 \\
\hline 14. & 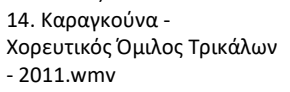 & www.youtube.com/watch?v=xryb5ILVLNM & In Greece & 700 & 17.12 .2011 & 21.11.2013 \\
\hline 15. & $\begin{array}{l}\text { 15. GreekFolkDance } \\
\text { "Кaragouna" • Гръцкитанц } \\
\text { "Карагуна" • Грчкаигра } \\
\text { "Карагуна" }\end{array}$ & www.youtube.com/watch?v=0_TsK7dWEvo & Outside Greece & 235 & 5.5.2013 & 28.11.2013 \\
\hline 16. & 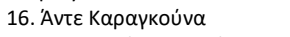 & www.youtube.com/watch?v=fmgLSQnPXo4 & In Greece & 3.223 & 9.10 .2012 & 21.11.2013 \\
\hline 17. & 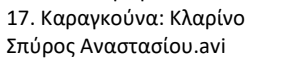 & www.youtube.com/watch?v=r_DroNyEkc4 & In Greece & 1.731 & 26.1.2012 & 21.11 .2013 \\
\hline 18. & $\begin{array}{l}\text { 18. "Karagouna" Greek } \\
\text { Dance at International Folk } \\
\text { Dance Club, Toronto }\end{array}$ & www.youtube.com/watch?v=1zLKzUJNTpU & Outside Greece & 464 & 29.11.2012 & 28.11 .2013 \\
\hline 19. & $\begin{array}{l}\text { 19. Karagouna SIFDAC CA } \\
\text { State Fair } 2006\end{array}$ & www.youtube.com/watch?v=6A6ZSn5IMKA & Outside Greece & 411 & 8.5.2012 & 28.11 .2013 \\
\hline
\end{tabular}

